\title{
Discovery Learning with Scaffolding To Promote Mathematical Creative Thinking Ability And Self-Efficacy
}

\author{
Mohamad Gilar Jatisunda ${ }^{*}$, Vici Suciawati ${ }^{2}$, Dede Salim Nahdi ${ }^{3}$ \\ 1,2,3 Universitas Majalengka, Indonesia
}

\section{Article Info \\ Submitted : 26-07-2020 \\ Revised : $06-12-2020$ \\ Accepted : $10-12-2020$ \\ Published : $17-12-2020$ \\ *Correspondence: \\ g.jatisunda@unma.ac.id}

\begin{abstract}
Mathematical creative thinking ability and self-efficacy are a combination of abilities students need to have when studying mathematics. Mathematics learning is expected to improve both abilities. However, teachers still use conventional learning, such as direct teaching, which results in a low increase in students' mathematical creative thinking abilities and self-efficacy. So we need alternative student-centred learning and teachers as facilitators who provide Scaffolding. The study was conducted to obtain a description of the discovery learning process with Scaffolding, aiming to improve the ability to think creatively and self-efficacy. Two quasi-experimental designs with three class groups, discovery learning with Scaffolding, discovery learning without Scaffolding, and conventional learning. The Matching-only Pretest-posttest Control Group Design was used to measure mathematical creative thinking skills, and The Matching-only Posttest-only Control Group Design was used to measure the scale self-efficacy. Based on one-way ANOVA results, students' mathematical creative thinking ability discovery learning with Scaffolding is better than discovery learning without Scaffolding and conventional learning. Likewise, this happens to 'self-efficacy, based on the one-way ANOVA that students' self-efficacy of discovery learning with Scaffolding is better than discovery learning without Scaffolding and conventional learning. The learning process of discovery learning with Scaffolding positively impacts improving mathematical creative thinking abilities and self-efficacy.
\end{abstract}

Key Words: Conventional learning; Discovery learning with Scaffolding; Discovery learning; Mathematical creative thinking ability; Self-efficacy.

\section{Introduction}

The role of mathematics in human inquiry is unique and privileged. It is the most comprehensive science of all and plays a significant role, if not all, in most scientific research (Colyvan, 2012; Shapiro, 2005). The standard approach is constructive to growing complexity gradually: from integer to fraction, real numbers, complex numbers, adding and multiplying, differentiation and integration, and higher mathematics (Russell, 1993). In the history of mathematics, we see a change from fairly concrete to more abstract in developing mathematical principles and methods (Ernest, 1985). The growth of mathematical concepts is developed in the human mind when socializing or discussing. Students do not think that every theory taught in the high school curriculum is not used in their lives (Glazer \& McConnell, 2002). Under the impact of computerization, automation, digitalization, and globalization, our society is evolving rapidly (Gravemeijer et al., 2017). Learning mathematics aims to prepare young people to have active mathematical activities, carry out mathematical processes, think mathematically and creatively, and solve open or closed mathematical problems (Suryadi, 2015). Each stakeholder must prepare the younger generation to develop critical analysis skills in mathematics usage in contexts outside 
mathematics and foster deep impressions of the younger generation on mathematics in social and cultural life and technology related to mathematics.

Indonesia is below the International average and has not been able to reach the Advance level. TIMSS and PISA is an independent educational performance measurement organization. A powerful example of children's educational skills is the barometer of quality education in mathematics, science, reading, and application in everyday lives (Johar, 2012). Indonesia ranks among countries year after year nearly as low (Argina et al., 2017; Stacey, 2011). There were 387 findings from PISA Indonesia's mathematics exams. Meanwhile, out of the average value of 500 (PISA, 2013), Indonesia's TIMMS results have been at 395 scores (Mullis et al., 2012). Based on the TIMMS results, Indonesian students' creative thinking skills level is relatively low, with only $2 \%$ of Indonesian students working on high and advanced category questions that require creative thinking skills to solve them (Mullis et al., 2012). The results TIMSS 2015, Indonesia ranked 44 out of 49 countries, with a low category of more than 50\% (Mullis et al., 2014). According to data from PISA 2015, only students can view or use algorithms in such a way that creative thinking can not be established (Qadri et al., 2019). Indonesia has been at a lower point in the top five (Utomo et al., 2018), as determined by the results of TIMSS over the last four years; Indonesia also needs to be evaluated, especially thinking competency (Fauziah et al., 2020).

Teaching methods in mathematics depends on powerful ways to understand mathematical concepts (Simon, 2020). Mathematical creativity ensures the development of the field of mathematics concepts (Sriraman, 2009). Mathematical creativity is hard to develop if one is restricted to rules without understanding the problem's meaning to be solved (Mann, 2006). The learning process's innovation needs to be done to improve mathematical creativity, starting from junior high school students to become a provision for them to explore mathematics to the next level. Based on the task-related orientation, mathematics is described as a science that mostly consists of problem-solving techniques and the discovery of structures and conceptual frameworks (e.g., if someone can overcome the mathematical problems, he/she will often discover anything new (links, laws, and terms) (Tossavainen et al., 2019). Discovery learning is an alternative learning process that is centered on student activities discovering concepts.

Discovery learning has been done a lot at every level of education. Research that has been conducted by Prasasti et al. (2019) at the elementary school level with discovery learning results can improve critical thinking skills. Based on Herdiana et al.'s (2017) research at junior high school, it can be concluded that discovery learning effectively improves problem-solving competency. Likewise, in research at the high school level Delfita et al. (2016), there is an increase in mathematics learning outcomes after using discovery learning. Another senior high school research showed that discovery learning could improve critical thinking skills (Nugraha et al., 2020). Based on these studies' results, it is proven to increase students' mathematics learning outcomes. However, based on the research, In'am \& Hajar (2017) at junior high school showed that the students' learning results were under a perfect category. Then the research results from Brunstein et al. (2009) with only a little guidance for each transformation, students performed the worst in the discovery condition. Illustrates how strong guidance and repetition may be needed to discover something that cannot be told (Bakker, 2018). Empirical studies over the past half-century have consistently shown that minimally guided instruction is less effective and less efficient than educational approaches that place a strong emphasis on guiding the student learning process (Sweller et al., 2007). There are two different views on discovery learning. On 
the one hand, discovery learning has succeeded in improving mathematics learning outcomes, but on the other hand, it turns out that discovery learning has failed to improve learning outcomes.

Discovery learning is minimal guidance (Schmid et al., 2009). Developing a successful teacher-student partnership has proven a highly effective approach (Jerome et al., 2009). There must be alternatives for students to discover the learning process carried out in the classroom, namely, direct guidance to each student according to their needs. Discovery Learning, teachers do not deliver materials or lessons immediately to students. However, students should be encouraged to seek whatever they want to know. As guidance, teachers can use Scaffolding to give specific tasks in the form of students' worksheets (Putra et al., 2018). Scaffolding in the discovery learning process is chosen to search for mathematical concepts free from misconceptions. Scaffolding has been shown to minimize the students' cognitive load while learning. It can improve the accuracy of completion of particular tasks (Könings et al., 2019). Scaffolding is used to solve problems that arise by students during the learning process to complement discovery learning.

Giving math assignments to students requires caution because when a teacher gives a task that is too difficult, this will give students frustration, and of course, it will be a cognitive load. Cognitive Load Theory shows that free exploration of highly complex learning processes can produce a heavy workload of memory detrimental to learning (Sweller, 2004). The mathematical task will be significant when students are experienced enough to solve problems (Kirschner et al., 2006). Students succeed in mathematics due to several factors; besides cognitive factors, noncognitive factors also determine students' success, such as student interest in mathematics and views on mathematics's importance (Norton, 2019). Evidence showed that self-efficacy in specific scientific fields is closely associated with academic achievement (Kohen et al., 2019; Sparks, 2014; Zhou et al., 2019). The successful learning of mathematics is estimated by the interactions of ambition, ability, interest, and self-efficacy of mathematics if students are less in building self-efficacy and eventually improve mathematical skills. (Czocher et al., 2019). Selfefficacy provides positive feelings about the importance of learning mathematics and has confidence in completing mathematical tasks.

Positive feelings (excitement and trust) increase self-efficacy, while negative feelings (anxiety and fatigue) decrease self-efficacy since they give physiological proof to the individual who is not "capable" of doing the job (Morris et al., 2017). Self-efficacy includes perseverance and dedication (Pajares, 1996). Self-efficacy relates to one's convictions for achievement (Joo et al., 2000). Bandura claimed four self-efficacy sources when developing self-efficacy: mastery experiences, vicarious experiences, social persuasions, and physiological and affective state. (Martin \& Mulvihill, 2019; van Rooij et al., 2019; Watson \& Marschall, 2019). The theory put forward by Albert Bandura provides new insights into a mental aspect that is the link between one's potential and the final result. The potential that someone has will be buried forever in the absence of adequate self-efficacy.

Discovery learning is designed and considered to create a good relationship between the teacher and students, avoiding any frustration that might occur from the assignments, designing appropriate assignments, and Scaffolding during the learning process. Each set of discovery learning processes are well-designed learning situations that support students to gain valuable knowledge from the mathematical concepts taught. Besides structured assignments that are designed for demanding students' persistence in completing them, so that in the end, students have good creative thinking skills and high self-efficacy as provisions in their lives, and of 
course, the nature of the goals of learning mathematics is achieved well. Based on the description above, the purpose of this study is to see the average difference in mathematical creative thinking skills and self-efficacy based on the learning model used, discovery learning with Scaffolding, discovery learning without Scaffolding, and conventional learning.

\section{The Research Methods}

This research method activities by conducting experiments (trials) to take the study's data based on trials' results. With the design type of The Matching Only Pretest-Posttest Control Group Design. The quasi-experimental design was used to compare two groups with the same characteristics before the intervention identified a comparison group similar to the intervention group in terms of the initial pre-intervention characteristics (White \& Sabarwal, 2014). The research was conducted in the junior high schools in West Java province, Indonesia, from Maret to April 2019. The research design used in this study is described as follows in Table 1.:

Table 1. The Matching-only Pretest-posttest Control Group Design (Fraenkel et al., 2011)

\begin{tabular}{cccc}
\hline$M$ & $O$ & $X_{1}$ & $O$ \\
$M$ & $O$ & $X_{2}$ & $O$ \\
\hline$M$ & $O$ & & $O$ \\
\hline
\end{tabular}

This study's design is divided into three classes, $X_{1}$ is a class that gets discovery learning with the help of Scaffolding, $X_{2}$ is a class that gets the discovery learning without Scaffolding, and finally, $C$ is a control class that gets conventional learning process. $M$ is the sample with the same characteristics, which has the same or nearly the same mathematics ability, so there is no bias. Class taking is not done randomly. Finally, $O$ is a pretest and post-test of mathematical creative thinking abilities.

While the research design used for affective aspects, namely mathematical self-efficacy, is a one-shot case study (Fraenkel et al., 2011). The design for affective aspects in this study is illustrated as follows in Table 2.:

Table 2. The Matching-only Posttest-only Control Group Design (Fraenkel et al., 2011)

\begin{tabular}{lll}
\hline$M$ & $X_{1}$ & $O$ \\
$M$ & $X_{2}$ & $O$ \\
\hline$M$ & & $O$ \\
\hline
\end{tabular}

The design of affective aspects, $M$ samples were not obtained randomly, $X_{1}$ is an experimental class that gets discovery learning with the help of Scaffolding, $X_{2}$ is an experimental class with discovery learning and $C$ is a control class with conventional learning, and finally, $O$ is a post-test on a self-efficacy scale.

The experimental class and the control class have the same characteristics by looking for classes with the same mathematical ability level using the same average first-semester student learning outcomes. However, class taking is not done randomly or with only one characteristic. The sampling technique was carried out, utilizing the purposive sampling technique. The sample was 101 students of class VIII junior high school 1 Majalengka Regency, West Java province of 
Indonesia in the 2018/2019 school year. While the research sample is students of class VIII-A as an experimental class using discovery learning with Scaffolding, class VIII-B using discovery learning, and VIII-C as a class as a control class using conventional learning models. This sampling technique is determined based on Purposive Sampling. The purpose of this kind of sampling is to be carried out effectively and efficiently, especially in monitoring the condition of the research subjects, the time determined, and the conditions of the study and licensing procedures.

The instruments in this study were tests of mathematical creative thinking ability and selfefficacy scale developed by researchers. Indicators and scoring using the scoring guidelines (Bosch, 2008) are presented in Table 3 as follow:

Table 3. Indicators and Guidelines for Scoring Creative Thinking Abilities

\section{Aspects of creative thinking} ability

\section{Student Answer}

Score

Wrong ideas, or not giving ideas to solve problems

Give ideas to solve the problem, but the statement given is still not right.

Fluency

Give the right idea to solve the problem

Give more than one idea to solve the problem, but the statement given is still inaccurate.

Give ideas to solve more than one problem, with the statement given incomplete or correct.

Giving the wrong way or strategy for adjusting the problem, not giving an answer, or giving answers in more than one way, but all are wrong.

Answering is only one way, but it is still wrong in the calculation, so the answer is wrong

Flexibility

Providing answers is only one way entirely and precisely.

Give answers in more than one way, but mistakes are still found in calculations.

Give answers in more than one way, and everything is right and right.

Not answering or giving a wrong answer

Answering with his strategy, but still found errors in solving problems.

Using a low-level strategy and other students' use of

Originality $60 \%$ has led to problem-solving.

Answering and using medium level strategies and $40 \%$ used by other students, has led to solutions and do the right problem-solving.

Answering and using medium level strategies and 20\% used by other students, has led to solutions and do the right problem-solving.

Incorrect answers, or do not provide detailed answers. 
They are providing incorrect answers without details.

Elaboration

Giving answers that are almost close to the truth, accompanied by incomplete details

Giving the right answer, but the details are less detailed 3

Providing the right answer with detailed details

Source: adapted from (Bosch, 2008)

To measure students' self-efficacy scales, indicators based on Bandura refer to 3 dimensions of self-efficacy: the magnitude level, generality dimension, and strength dimension (Maddux, 2002). presented in Table 4 as follows:

Table 4 Indicator of Self-Efficacy in Solving Mathematical Problems

No. Indicators
1 Confident of completing specific tasks, the individual believes that he can complete
certain tasks, which is the individual himself who sets the task (target) what must be
completed
Sure, they can motivate to take the actions needed to complete the task; individuals can
foster motivation to choose and put the actions needed to complete the task.
Confident that he can try hard, persevering, and persevering. There is a strong effort
from individuals to complete the assigned tasks using all their resources
Be sure that you can face obstacles and difficulties. Individuals can survive when facing
difficulties and obstacles that arise and can rise from failure
Sure, they can complete tasks that have a wide or narrow range (specific). Individuals
believe that any task he can finish, even if it is broad or specific.

Source: adapted from Maddux, (2002)

The test is used to measure students' mathematical creative thinking abilities (pretest and post-test) then during the post-test implementation, and a scale was given to measure students' self-efficacy in each class. The mathematical creative thinking ability test questions in this study refer to the VIII semester 1 class subject matter. The set of questions for the mathematical creative thinking ability is a description of five questions to see the explanation form's mentality. The compilation of questions begins with creating an instrument grid that includes competency standards, essential competencies, learning indicators, and measurable ability indicators. After making the problem lattice, then compile questions that are essays of critical mathematical creative thinking abilities and answer keys that refer to the assessment guidelines, then make a scale of mathematical self-efficacy.

Quantitative data were obtained from the results of tests of mathematical creative thinking abilities and self-efficacy. The data of the mathematical creative thinking ability test score analyzed is original data. As for the self-efficacy data analyzed are processed data. Because the score on the self-efficacy scale is in the form of an ordinal scale. So this data must first be transformed into interval data with the Successive Method Interval (MSI). The steps used to analyze students' mathematical creative thinking score data are as follows: 1) Pretest and posttest data from the three classes (two experimental classes and one control class), then the data is usually distributed and has a homogeneous variant, then a one-way ANOVA test is performed. 2) Regression analysis is used to analyze the effects of self-efficacy on mathematical creative thinking abilities. 


\section{The Results of the Research and the Discussion}

The research results that have been carried out are mathematical creative thinking ability tests and self-efficacy scale. Based on the analysis of three classes (two experimental classes and one control class), they are typically distributed and have homogeneous variants. One-way ANOVA analysis is used to test that all three classes have the same characteristics. Table 3 provides information that there were no significant differences in the pretest between the three classes.

Table 5. Score Pre-test Experimental and Control Class with One-Way ANOVA Test

\begin{tabular}{lrrrrc}
\multicolumn{1}{c}{ Score Pretest } & \multicolumn{1}{c}{ SS } & \multicolumn{1}{c}{ df } & \multicolumn{1}{c}{ MS } & $\boldsymbol{F}$ & $\boldsymbol{p}$ \\
Between Groups & 32.732 & 2 & 16.918 & 1.567 & .246 \\
Within Groups & 1080.425 & 98 & 11.923 & & \\
\hline Total & 1204.248 & 100 & & & \\
\hline
\end{tabular}

They are focusing on the one-way ANOVA results for the initial study (pretest) in Table 5. The hypothesis is formulated in the form of a statistical hypothesis (two-tailed) as follows:

$\mathrm{H}_{0}: \mu_{1}=\mu_{2}$

$\mathrm{H}_{1}: \mu_{1} \neq \mu_{2}$,

by:

$H_{0}$ : Students' mathematical creative thinking abilities in the two experimental classes and the control class on the final test (post-test) are not significantly different.

$H a$ : Students' mathematical creative thinking skills in two experimental classes and the control class on the final test (post-test) are significantly different or not the same.

The value is more significant than $p>.05$, so that $H_{0}$ is accepted and $H_{a}$ is rejected. It can be concluded that the skills of the two experimental classes of creative mathematical thinking and one control class on the initial test (pretest) are not much different or equivalent. The three classes (two experimental classes and one control class) are typically distributed and have homogeneous variances based on the following summary results. These results are the same as the results of tests carried out by Suciawati (2016); Sundayana (2012); these results indicate that the three classes' abilities used as the study object have the same mathematical abilities. Table 4 provides information that there is no significant difference in post-test among the three classes.

Table 6. Score Posttest Experimental and Control Class with One-Way ANOVA Test

\begin{tabular}{lrrrrr} 
Score Posttest & \multicolumn{1}{c}{ SS } & df & MS & F & p \\
\hline Between Groups & 247.262 & 2 & 123.582 & 3.276 & .044 \\
Within Groups & 3718.384 & 98 & 37.842 & & \\
\hline Total & 3965.456 & 100 & & & \\
\hline
\end{tabular}

Based on the findings in Table 6 of the one-way ANOVA test for the final test (post-test). The hypothesis is formulated in the form of a statistical hypothesis (two-tailed) as follows:

$\mathrm{H}_{0}: \mu_{1}=\mu_{2}$

$\mathrm{H}_{1}: \mu_{1} \neq \mu_{2}$,

by:

$H_{0}$ : Students' mathematical creative thinking abilities in the two experimental classes and the control class on the final test (post-test) are not significantly different or the same. 
Ha: Students' mathematical creative thinking skills in two practical classes and the control class on the final test (post-test) are significantly different or not the same.

The value means less than $p<.05$, so $H_{0}$ is rejected, and $H_{a}$ is accepted, or it can be concluded that students' ability for two experimental classes and one control class in the final test (post-test) is different or not the same. These results are following the research results of Mandasari (2016), Purwaningrum (2016), Suriany (2016) that students' creative thinking abilities in the experimental class and control class differ significantly. The analysis proceeds to a comparison or posthoc analysis section to find out the differences in the final abilities of the mathematical creative thinking abilities of the two experimental groups, and one control group are presented in Table 7.:

Table 7. Result of Tukey Posthoc

\begin{tabular}{|c|c|c|c|c|c|c|}
\hline \multirow[b]{2}{*}{ (i) Class } & \multirow[b]{2}{*}{ (j) Class } & \multirow{2}{*}{$\begin{array}{c}\text { Mean } \\
\text { Difference } \\
\text { (i-j) }\end{array}$} & \multirow[b]{2}{*}{ SE } & \multirow[b]{2}{*}{$\boldsymbol{P}$} & \multicolumn{2}{|c|}{$95 \%$ Confidence Interval } \\
\hline & & & & & $\begin{array}{l}\text { Lower } \\
\text { Bound }\end{array}$ & $\begin{array}{l}\text { Upper } \\
\text { Bound }\end{array}$ \\
\hline $\begin{array}{l}\text { Discovery } \\
\text { Learning } \\
\text { with }\end{array}$ & $\begin{array}{l}\text { Discovery } \\
\text { Learning } \\
\text { Without } \\
\text { Scaffolding }\end{array}$ & 2.34 & 1.604 & .34 & -1.26 & 5.92 \\
\hline Scaffolding & $\begin{array}{c}\text { Conventional } \\
\text { Learning } \\
\text { Discovery }\end{array}$ & $3.86^{*}$ & 1.524 & .00 & .26 & 7.47 \\
\hline $\begin{array}{l}\text { Discovery } \\
\text { Learning } \\
\text { Without }\end{array}$ & $\begin{array}{l}\text { Learning } \\
\text { with } \\
\text { Scaffolding }\end{array}$ & -2.34 & 1.524 & .34 & -5.92 & 1.26 \\
\hline Scaffolding & $\begin{array}{l}\text { Conventional } \\
\text { Learning }\end{array}$ & 1.63 & 1.482 & .00 & -2.01 & 5.06 \\
\hline & $\begin{array}{l}\text { Learning } \\
\text { with }\end{array}$ & $-3.76^{*}$ & 1.516 & .34 & -7.45 & -.26 \\
\hline $\begin{array}{l}\text { Conventional } \\
\text { Learning }\end{array}$ & $\begin{array}{l}\text { Scaffolding } \\
\text { Discovery } \\
\text { Learning } \\
\text { Without } \\
\text { Scaffolding }\end{array}$ & -1.64 & 1.482 & .00 & -5.06 & 2.01 \\
\hline
\end{tabular}

*The mean difference is significant at the .05 level

The results based on Table 7 show that students 'mathematical creative thinking with discovery learning with scaffolding learning does differ significantly from students' mathematical creative thinking in discovery learning without scaffolding classes $(p<.05)$. Mathematical creative thinking ability of students discovery learning with Scaffolding there is a gap between students' mathematical creative thinking ability with conventional learning $(p<.05)$. The final ability of students' mathematical creative thinking abilities in the discovery learning experimental class is different from the mathematical creative thinking abilities of students in conventional learning control classes $(p<.05)$. 
Table 8. Score Self-efficacy Experiment and Control Class with One-way ANOVA Test

\begin{tabular}{lrrrrr}
\multicolumn{1}{c}{$\begin{array}{c}\text { Score Self- } \\
\text { efficacy }\end{array}$} & \multicolumn{1}{c}{ SS } & df & \multicolumn{1}{c}{ MS } & $\boldsymbol{F}$ & $\boldsymbol{p}$ \\
\hline Between Groups & 607.436 & 2 & 303.719 & 3.607 & .032 \\
Within Groups & 8353.118 & 98 & 84.216 & & \\
\hline Total & 8950.552 & 100 & & & \\
\hline
\end{tabular}

Based on the results of the one-way ANOVA test for self-efficacy in Table 8. The hypothesis is formulated in the form of a statistical hypothesis (two-party test) as follows:

$\mathrm{H}_{0}: \mu_{1}=\mu_{2}$

$\mathrm{H}_{1}: \mu_{1} \neq \mu_{2}$,

by:

$H_{0}$ : Students' self-efficacy of the two experimental classes and the conventional class are not significantly different or the same

$H a$ : students' self-efficacy of the two experimental classes and the conventional class are significantly different or not the same

It appears that $\mathrm{p}<.05$ so that $H_{0}$ is rejected and $\mathrm{Ha}$ is accepted, or it can be concluded that the two experimental and control classes' self-efficacy is significantly different or not the same. Then proceed to post hoc analysis to find out the differences of each student's self-efficacy in the two experimental groups and one control group, in detail, as follows in Table 7.:

Table 9. Tukey Post-hoc

\begin{tabular}{|c|c|c|c|c|c|c|}
\hline \multirow[b]{2}{*}{ (i) } & \multirow[b]{2}{*}{ (j) } & \multirow{2}{*}{$\begin{array}{c}\text { Mean } \\
\text { Difference } \\
(\mathbf{i}-\mathbf{j})\end{array}$} & \multirow[b]{2}{*}{ SE } & \multirow[b]{2}{*}{$p$} & \multicolumn{2}{|c|}{$\begin{array}{l}\text { 95\% Confidence } \\
\text { Interval }\end{array}$} \\
\hline & & & & & $\begin{array}{l}\text { lower } \\
\text { bound }\end{array}$ & $\begin{array}{l}\text { upper } \\
\text { bound }\end{array}$ \\
\hline $\begin{array}{l}\text { Discovery } \\
\text { Learning } \\
\text { with }\end{array}$ & $\begin{array}{l}\text { Discovery } \\
\text { Learning } \\
\text { without } \\
\text { Scaffolding }\end{array}$ & $-5.468^{*}$ & 2.245 & .045 & -10.9 & -.118 \\
\hline Scaffolding & $\begin{array}{c}\text { Conventiona } \\
\text { 1 Learning } \\
\text { Discovery }\end{array}$ & -5.062 & 2.261 & .031 & -1.433 & .327 \\
\hline $\begin{array}{c}\text { Discovery } \\
\text { Learning } \\
\text { without }\end{array}$ & $\begin{array}{l}\text { Learning } \\
\text { with } \\
\text { Scaffolding }\end{array}$ & $5.468 *$ & 2.245 & .045 & .118 & 109 \\
\hline Scaffolding & $\begin{array}{l}\text { Conventiona } \\
1 \text { Learning } \\
\text { Discovery }\end{array}$ & 0.426 & 2.210 & .03 & -4.853 & 5.665 \\
\hline & $\begin{array}{l}\text { Learning } \\
\text { with }\end{array}$ & 5.062 & 2.261 & .31 & -.327 & 10.433 \\
\hline $\begin{array}{l}\text { Convention } \\
\text { al Learning }\end{array}$ & $\begin{array}{l}\text { Scaffolding } \\
\text { Discovery } \\
\text { Learning } \\
\text { without } \\
\text { Scaffolding }\end{array}$ & 0.426 & 2.210 & .03 & -5.665 & 4.853 \\
\hline
\end{tabular}

*The mean difference is significant at the .05 level 
Table 9. shows a gap between discovery learning with scaffolding and discovery learning without scaffolding classes in self-efficacy $(p<.05)$. There was a difference significantly between discovery learning with scaffolding students and conventional classes in self-efficacy $(p<.05)$, and there is a difference between discovery learning without scaffolding class and conventional class in Self-efficacy $(p<.05)$. Based on the assumption test results that the two experimental classes were normally distributed and had a homogeneous variance, then the oneway ANOVA test was performed through the significance level of $\alpha=.05$. After processing the data, the output display can be seen in the following Table 10.:

\section{Table 10. Score Self-efficacy Discovery Learning with Scaffolding Class And Discovery} LearningWithout Scaffolding Class

\begin{tabular}{lrrrrr}
\multicolumn{1}{c}{$\begin{array}{c}\text { Score Self- } \\
\text { efficacy }\end{array}$} & \multicolumn{1}{c}{ SS } & df & \multicolumn{1}{c}{ MS } & \multicolumn{1}{c}{$\boldsymbol{F}$} & $\boldsymbol{p}$ \\
\hline Between Groups & 498.145 & 1 & 498,145 & 5,309 &, 024 \\
Within Groups & 6098,824 & 65 & 93,828 & & \\
\hline Total & 6596,969 & 66 & & & \\
\hline
\end{tabular}

Based on the two experimental groups' results from the one-way ANOVA test in Table 10, the hypothesis is formulated in the form of a statistical hypothesis (one-tailed test) as follows:

$\mathrm{H}_{0}: \mu_{1} \leq \mu_{2}$

$\mathrm{H}_{1}: \mu_{1}>\mu_{2}$

by :

$H_{0}$ : Students' self-efficacy in the discovery learning with scaffolding class was not better or equal to that of the students in the discovery learning without scaffolding class.

$H a$ : Students' self-efficacy in the discovery learning with scaffolding class was better than students in the discovery learning without scaffolding class.

Using a one-tailed test, $\mathrm{p}<.05, \mathrm{H}_{0}$ rejected, and $\mathrm{Ha}$ can conclude that the self-efficacy of discovery learning with Scaffolding is better than discovery learning without Scaffolding students. Based on the assumption test calculation that the two classes' post-test data is typically distributed and has a homogeneous variance, a one-way ANOVA test was performed with a significance level of $\alpha=.05$. After processing the data, the output display can be seen in Table 11. as follow:

Table 11. Score Self-Efficacy Discovery Learning With Scaffolding Class And Conventional Learning Class

\begin{tabular}{lrrrrr}
\multicolumn{1}{c}{$\begin{array}{c}\text { Score Self- } \\
\text { efficacy }\end{array}$} & \multicolumn{1}{c}{ SS } & df & MS & $\boldsymbol{F}$ & $\boldsymbol{p}$ \\
\hline Between Groups & 430,897 & 1 & 420,896 & 4,121 &, 047 \\
Within Groups & 6536,196 & 64 & 102,128 & & \\
\hline Total & 6967,083 & 65 & & & \\
\hline
\end{tabular}

Based on the one-way ANOVA test results in Table 11. for both classes based on them, The hypothesis is formulated in the form of a statistical hypothesis (one-party test) as follows:

$\mathrm{H}_{0}: \mu_{1} \leq \mu_{2}$

$\mathrm{H}_{1}: \mu_{1}>\mu_{2}$ by :

$H_{0}$ : Students' self-efficacy in the discovery learning with scaffolding class is not better or equal to that of conventional class students. 
$H_{1}$ : The self-efficacy of students in the discovery learning with scaffolding class is better than conventional class students.

Then $\mathrm{p}<.05$ so that $H_{0}$ is rejected and $H_{l}$ is accepted,s it can be concluded that the discovery learning class's self-efficacy is better than conventional learning classes. Based on the assumption test that the two classes' pretest data is typically distributed and has a homogeneous variance, a one-way ANOVA test is then performed with a significance level of $\alpha=.05$. After processing data, the output display can be seen in the following Table 12.:

Table 12. Score Self-Efficacy Discovery Learning Without Scaffolding Class and Conventional Learning Class

\begin{tabular}{lrlrll}
\multicolumn{1}{c}{ Score Pretest } & \multicolumn{1}{c}{ SS } & df & \multicolumn{1}{c}{ MS } & $\boldsymbol{F}$ & $\boldsymbol{p}$ \\
\hline Between Groups & 2,931 & 1 & 2,842 &, 049 &, 825 \\
Within Groups & 3871,234 & 67 & 57,780 & & \\
\hline Total & 3874,077 & 68 & & & \\
\hline
\end{tabular}

The hypothesis is formulated in the form of a statistical hypothesis (one-party test) as follows:

$\mathrm{H}_{0}: \mu_{1} \leq \mu_{2}$

$\mathrm{H}_{1}: \mu_{1}>\mu_{2}$

by :

$H_{0}$ : Students' self-efficacy in the discovery learning class is not better or the same as that of conventional class students.

$H a$ : The self-efficacy of students in the discovery learning class is better than conventional class students.

Based on the results of the one-way ANOVA test in Table 13 for both classes based on the results of the test $\mathrm{p}>.05$ so that $H_{0}$ is accepted and $H_{a}$ is rejected, or it can be concluded that the Self-efficacy of discovery learning class students is no better than students with conventional learning. In general, there are two types of relationships between two or more variables, namely the form of a relationship and the closeness of a relationship. To find out the form of the relationship used regression analysis, while for the relationship's closeness, used correlation analysis. To analyze the effect of mathematical creative thinking ability with self-efficacy used regression analysis. Regression analysis is defined as a study that studies the dependence of one variable, a variable explained by one or two explaining variables. Test results with a significant level of regression analysis are shown in Table 13.:

Tabel 13. Result of Regression Analysis

\begin{tabular}{|c|c|c|c|c|c|}
\hline \multirow[t]{2}{*}{ Model } & \multicolumn{2}{|c|}{$\begin{array}{l}\text { Unstandardized } \\
\text { Coefficients }\end{array}$} & \multirow{2}{*}{$\begin{array}{c}\text { Standardized } \\
\text { Coefficients } \\
\text { Beta }\end{array}$} & \multirow[t]{2}{*}{$\mathbf{t}$} & \multirow[t]{2}{*}{$p$} \\
\hline & B & SE & & & \\
\hline Constant & 78.637 & 4.052 & & 19.742 & .000 \\
\hline Creative Thinking & .182 & .154 & .126 & 1.262 & .003 \\
\hline
\end{tabular}

From Table 13. above, the significance value of the regression coefficient is $p<.05$, which means that $\mathrm{HO}$ is rejected, that there is an effect of mathematical creative thinking ability on students' self-efficacy. Furthermore, this table also illustrates the regression equation as follows: $\mathrm{Y}=78.637+0.182 \mathrm{X}+\mathrm{e}$ (Rawlings et al., 2001) 
Information:

$\mathrm{X}=$ data of mathematical creative thinking ability

$\mathrm{Y}=$ data self-efficacy

The regression equation above shows that the value of $A=78.637$ and $B=0.182$. The value of $\mathrm{B}$ obtained is positive, which states that the variable $\mathrm{X}$ has a positive effect on the value of the dependent variable $\mathrm{Y}$, which means that the ability to think mathematically positively affects self-efficacy. These results are consistent with previous research that has been conducted by several researchers, namely Karina (2019) and Suciawati (2019), with the result that self-efficacy has a positive influence on mathematical thinking creative ability.

This recent study uses three types of learning models discovery learning with Scaffolding, discovery learning without Scaffolding, and conventional learning. The study results show no significant differences in third-class students' creative thinking ability before treatment because all three classes are teacher-centered learning. The emphasis of conventional learning is more on the teacher-centered learning process. Teacher-centered mathematics learning implements an interactive learning process, so students will think and do things that can make them understand mathematics's learning process (Balim, 2009; Meidawati, 2013; Muchyidin, 2017; Siregar, 2015). As the research results described in the previous section, the results show that discovery learning with Scaffolding can develop mathematical creative thinking abilities. The average final test data score that gets supervised discovery learning is higher than the average final test data score that gets discovery learning and conventional learning.

Several previous studies have collaborated on discovery learning. One of them is collaborating discovery learning with a scientific approach with the result gives better mathematics learning achievement and improve self-efficacy (Ramdhani et al., 2017). Another collaboration is discovery learning with the cultural context in which students live; the second trial results showed that learning materials based guided discovery learning with Batak Toba context improved students' mathematical problem-solving ability and self-efficacy significantly (Simamora et al., 2019). Another research gives the results of data that GeoGebra's utilization in discovery learning could solve problems and attitudes towards mathematics are better (Murni et al., 2017). Discovery learning with an approach or even with computer-assisted instruction has a more positive impact on improving learning achievement. The learning process using discovery learning with Scaffolding refers to the minimum completeness criteria, resulting in an average of students above the minimum completeness criteria. Using statistical analysis of inference learning, discovery learning with Scaffolding is better than conventional learning (Nugroho et al., 2020).

Criticism of discovery learning is a learning process carried out at a minimum of guidance (Kirschner et al., 2006). Discovery learning is used to improve higher-level abilities, such as mathematical resilience. The research results are more recommended to use problem-based learning when discovery learning is used (Hafiz \& Dahlan, 2017). Research suggests that unassisted discovery does not benefit learners, whereas feedback Scaffolding the learner and the explanations obtained is useful (Alfieri et al., 2011). Direct instruction is more effective than discovery learning in teaching (Klahr \& Nigam, 2004). Discovery learning provided benefits when a new strategy had to be generated to solve problem-solving (McDaniel \& Schlager, 1990). Based on this, integrating scaffolding theory into the learning process of discovery becomes very important to be carried out together. Discovery learning combines with Scaffolding to understand and solve problems by guiding the discovery of facts, relationships, and solutions 
by students (Lavine, 2012). The steps or phases in discovery learning with Scaffolding allow students to obtain their knowledge. However, the teacher's role is also significant in directing students not to understand the learned concepts. These findings indicate that directed discovery learning has demonstrated students' potential to improve their creative mathematical thinking. It can thus be inferred that directed learning plays a better role in improving innovative thinking skills than discovery learning and ordinary learning.

The assignments given to students in this study are designed and packaged to experience stages following discovery learning with Scaffolding, from formulating the problem to evaluating their findings. The assignment's design is given to be in line with the objectives of the conceptual Scaffolding, which aims to develop a conceptual understanding (Frederick et al., 2014; Ormond, 2016). The questions are packaged in the form of story questions that apply daily activities and can be solved in many ways (Al-Yami, 2008). Following the learning stages of discovery learning with Scaffolding, students are asked to formulate what problems must be done to obtain a solution. In the first stage of formulating the problem, students are directed so that they can formulate a solution based on data or information available on the problem; in this case, the teacher asks students to read the questions carefully, record what is known and what is asked, guess the direction of the solution that might be done. The second stage is to construct a conjecture; at this stage, students are directed indirectly to make links between existing information and prior knowledge and then compile these estimates from the data analysis results (Gijlers \& De Jong, 2005). There is an interaction between students in conducting the discovery activity; this condition will affect the students 'mastery of mathematical material and improve students' social skills (Patandung, 2017; Prasetyana et al., 2015; Sibuea et al., 2019).

The aim is to influence students to think each other, and the teacher acts as a facilitator in providing indirect guidance to students; the teacher provokes students' thinking by providing focused questions so that they can enable students to understand and construct certain concepts, construct rules and learn to find something to solve problems. The next step is to formulate concepts from estimates that have been made previously to solve problems. From the findings in the field in solving problems encountered, some students have not succeeded in solving the problem; the teacher assists in the form of directing questions such as, check whether there is previous information wrong or incomplete and try to repeat it more thoroughly so that can solve the problem. At this stage, the teacher asks students to give questions and discuss them with their classmates or group members. The assistance provided by the teacher is not direct but is a question that provokes students with their new ideas.

As the last stage of evaluating, students are asked to recheck their answers and draw conclusions from their work, finding common problem-solving forms. By giving students the freedom to solve problems and applying them to the scaffold, learning can awaken their creative potential. Students are invited to explore the problems they face; they are also invited to develop ideas on how to solve these problems. So that learning is not fixed on patterns that already exist, students are given the freedom to solve problems in their way even though at the end of learning activities, students with the help of teachers must still make conclusions that are following existing mathematical concepts. From the findings, it can be seen that the learning model factors have a significant influence on students' mathematical creative thinking abilities. Discovery learning with Scaffolding can develop creative thinking abilities.

Based on the statistical tests, selecting the three classes that will serve as research samples comes from a homogeneous population. It means that there is no difference in students' 
mathematical thinking abilities using discovery learning with Scaffolding, discovery learning without Scaffolding, and conventional learning. It shows that the readiness or creative thinking ability of students who use discovery learning with Scaffolding, discovery learning without, and conventional learning is relatively the same. This situation is conducive to seeing students' mathematical creative thinking abilities after learning occurs (Nurdjito, 2013; Rahmazatullaili et al., 2017). An analysis of the results after learning is carried out in three classes with different learning, namely discovery learning with Scaffolding, discovery learning without Scaffolding, and conventional learning. It can be inferred that there are significant differences in mathematical creative thinking abilities. Students use discovery learning with Scaffolding better than those using discovery learning without Scaffolding and conventional learning about Mathematical creative thinking ability.

Open problems are given to students to try to get answers and emphasize how they go through students to arrive at the desired answers. Students can develop different methods or ways to solve problems. Provides opportunities for students to do greater elaboration to develop their mathematical thinking skills and foster students' creative activities in solving problems. The process through which it provides meaningful experiences to students in learning mathematics and gives confidence impacts their abilities. The results obtained from the spread of a selfefficacy scale questionnaire showed that students' self-efficacy using discovery learning with Scaffolding was better than students who used discovery learning and conventional learning. Individuals with positive self-concepts will help improve student achievement simultaneously (Marsh \& Scalas, 2011). Individuals can appraise relationships correctly and foster reasonable social adjustment (Wang \& Lin, 2007). In this case, students' mathematical creative thinking abilities have an essential role in supporting self-efficacy to be more confident and confident in learning mathematics. Therefore, students who use discovery learning with Scaffolding are better than the self-efficacy of students who use discovery learning and conventional learning. Students with low self-efficacy might avoid learning many tasks, incredibly challenging tasks, while students with high self-efficacy have a strong desire to work on their assignment (Schunk, 1995)

The higher the mathematical creative thinking ability is, the higher the self-efficacy is, and vice versa. Can be seen from the regression equation, which shows that the coefficient of the variable $\mathrm{X}$ is positive. So, it can be concluded that there is an influence of mathematical creative thinking ability on self-efficacy that uses discovery learning with Scaffolding, discovery learning without Scaffolding, or conventional learning. Ability and self-efficacy are two different things. A student might show high self-efficacy but do not have enough knowledge or ability related to the material's substance (Pajares, 2002). However, if two students have the same ability but have different self-efficacy, it is believed that they will show different abilities. Students who have high self-efficacy will be more persistent, determined, and interested in exporting new things. Allows students to have more ability than students who do not show such behavior. This knowledge causes students to have specific abilities. Thus, it can be said that the mathematical self-efficacy prerequisites that support the development of creative mathematical thinking. Students with low self-efficacy may avoid learning many tasks, incredibly challenging tasks, while high self-efficacy students have a strong desire to work on their tasks (Schunk, 1995; Sumarmo, 2010).

Student activities that use discovery learning with Scaffolding from the first meeting to the sixth meeting experience a change towards a better attitude. Based on the analysis, student activities in classes using discovery learning with Scaffolding are greater than student activities 
in classes using discovery learning without Scaffolding and conventional learning. Because students dominate more activities when learning occurs, they do not hesitate to ask questions and always discuss with the group. In contrast to classes that use conventional learning and learning, student activities in conventional classroom learning only occasionally ask the teacher to be passive. Students work on problems individually so that interaction between students and students rarely occurs. In general, for students learning discovery, learning with Scaffolding helps give understanding and confidence in solving mathematical problems. Even some of them revealed the questions given by the teacher were still lacking and always wanted to try to solve the next problem. So that it raises a sense of not being ashamed in asking if there are things that do not understand both the group of friends and the teacher

\section{Conclusion and Suggestion}

The pretest data analysis results show no significant difference, which means that each research subject's mathematical abilities have the same characteristics. This result indicates that the research subject is representative to be the research sample. The mean difference test results in the three classes have proven that each class is significantly different. Based on the one-way ANOVA test to see the difference in the average creative thinking ability of two experimental classes and one control class, there is a significant difference in the three classes' average creative thinking ability. The posthoc test strengthens this result. Likewise, the one-way ANOVA test results to see differences in self-efficacy in each class. There are significant differences in the average self-efficacy in each class.

This result means that discovery learning with Scaffolding positively impacts students' creative thinking skills and self-efficacy. The last is testing using simple linear regression to see the effect of self-efficacy on thinking creatively, with self-efficacy results having a positive effect. Suggestions for further research are to focus more on scaffolding theory because it turns out that not all student-centered learning models have a good influence on student learning processes. When faced with learning difficulties, it will harm cognitively or psychologically. However, the Scaffolding given at the time of this research was too intensive at every meeting, so it was not good because the Scaffolding would be useful if the students' time and energy in doing the assignments were adequate.

\section{References}

Al-Yami, S. A. (2008). The Effectiveness of Scaffolding Interactive Activities in Developing the English Listening Comprehension Skills of the Sixth Grade Elementary Schoolgirls in Jeddah. Online Submission.

Alfieri, L., Brooks, P. J., Aldrich, N. J., \& Tenenbaum, H. R. (2011). Does discovery-based instruction enhance learning? Journal of Educational Psychology, 103(1), 1.

Argina, A. W., Mitra, D., Ijabah, N., \& Setiawan, R. (2017). Indonesian PISA Result: What Factors and What Should Be Fixed? Proceedings Education and Language International Conference, $1(1)$.

Bakker, A. (2018). Discovery learning: zombie, phoenix, or elephant? Instructional Science, 46(1), 169-183. https://doi.org/10.1007/s11251-018-9450-8

Balim, A. G. (2009). The Effects of Discovery Learning on Students' Success and Inquiry Learning Skills. Eurasian Journal of Educational Research (EJER), 35. 
Bosch, N. (2008). Rubric for Creative Thinking Skills Evaluation. Retrieved June, 20, 2012.

Brunstein, A., Betts, S., \& Anderson, J. R. (2009). Practice enables successful learning under minimal guidance. Journal of Educational Psychology, 101(4), 790. https://doi.org/10.1037/a0016656

Colyvan, M. (2012). An introduction to the philosophy of mathematics. Cambridge University Press.

Czocher, J. A., Melhuish, K., \& Kandasamy, S. S. (2019). Building mathematics self-efficacy of STEM undergraduates through mathematical modelling. International Journal of Mathematical Education in Science and Technology, 1-28.

Delfita, O., Kartini, K., \& Sakur, S. (2016). Penerapan Model Discovery Learning untuk Meningkatkan Hasil Belajar Matematika Siswa Kelas X Mia 4 SMA Negeri 5 Pekanbaru. Riau University.

Ernest, P. (1985). The philosophy of mathematics and mathematics education. International Journal of Mathematical Education in Science and Technology, 16(5), 603-612.

Fauziah, M., Marmoah, S., Murwaningsih, T., \& Saddhono, K. (2020). Profile of divergent thinking ability of elementary school student in thematic learning. Elementary Education Online, 19(2), 624-640.

Fraenkel, J. R., Wallen, N. E., \& Hyun, H. H. (2011). How to design and evaluate research in education. New York: McGraw-Hill Humanities/Social Sciences/Languages. https://pdfs.semanticscholar.org/60b6/99eda714ac21599455741fb499dd4e68f615.pdf

Frederick, M. L., Courtney, S., \& Caniglia, J. (2014). With a little help from my friends: Scaffolding techniques in problem solving. Investigations in Mathematics Learning, 7(2), 21-32. https://doi.org/doi.org/10.1080/24727466.2014.11790340

Gijlers, H., \& De Jong, T. (2005). The relation between prior knowledge and students' collaborative discovery learning processes. Journal of Research in Science Teaching: The Official Journal of the National Association for Research in Science Teaching, 42(3), 264282.

Glazer, E., \& McConnell, J. W. (2002). Real-life math: Everyday use of mathematical concepts. Greenwood Press.

Gravemeijer, K., Stephan, M., Julie, C., Lin, F.-L., \& Ohtani, M. (2017). What mathematics education may prepare students for the society of the future? International Journal of Science and Mathematics Education, 15(1), 105-123.

Hafiz, M., \& Dahlan, J. A. (2017). Comparison of Mathematical Resilience among Students with Problem Based Learning and Guided Discovery Learning Model. JPhCS, 895(1), 12098.

In'am, A., \& Hajar, S. (2017). Learning Geometry through Discovery Learning Using a Scientific Approach. International Journal of Instruction, 10(1), 55-70.

Jerome, E. M., Hamre, B. K., \& Pianta, R. C. (2009). Teacher--child relationships from kindergarten to sixth grade: Early childhood predictors of teacher-perceived conflict and closeness. Social Development, 18(4), 915-945.

Johar, R. (2012). Domain soal PISA untuk literasi matematika. Jurnal Peluang, 1(1), 30. 
Joo, Y.-J., Bong, M., \& Choi, H.-J. (2000). Self-efficacy for self-regulated learning, academic self-efficacy, and Internet self-efficacy in Web-based instruction. Educational Technology Research and Development, 48(2), 5-17.

Karina, D. (2019). Pengaruh Model Pembelajaran Brain Based Learning terhadap Kemampuan Berpikir Kreatif Matematis dan Self-Efficacy Siswa SMP. (Doctoral dissertation, FKIP UNPAS).

Kirschner, P. A., Sweller, J., \& Clark, R. E. (2006). Why minimal guidance during instruction does not work: An analysis of the failure of constructivist, discovery, problem-based, experiential, and inquiry-based teaching. Educational Psychologist, 41(2), 75-86. https://doi.org/https://doi.org/10.1207/s15326985ep4102_1

Klahr, D., \& Nigam, M. (2004). The equivalence of learning paths in early science instruction: Effects of direct instruction and discovery learning. Psychological Science, 15(10), 661667.

Kohen, Z., Amram, M., Dagan, M., \& Miranda, T. (2019). Self-efficacy and problem-solving skills in mathematics: the effect of instruction-based dynamic versus static visualization. Interactive Learning Environments, 1-20.

Könings, K. D., van Zundert, M., \& van Merriënboer, J. J. G. (2019). Scaffolding peerassessment skills: Risk of interference with learning domain-specific skills? Learning and Instruction, 60, 85-94. https://doi.org/https://doi.org/10.1016/j.learninstruc.2018.11.007

Lavine, R. (2012). Guided Discovery Learning. Encyclopedia of the Sciences Of.

Maddux, J. E. (2002). Self-efficacy. Handbook of Positive Psychology, 277-287.

Mandasari, L. (2016). Peningkatan Kemampuan Berpikir Kreatif Matematis Siswa SMA Melalui Problem Based Learning Menggunakan Software Autograph. Jurnal As-Salam, 1(1), 143152.

Mann, E. L. (2006). Creativity: The essence of mathematics. Journal for the Education of the Gifted, 30(2), 236-260.

Marsh, H. W., \& Scalas, L. F. (2011). Self-concept in learning: Reciprocal effects model between academic self-concept and academic achievement. Social and Emotional Aspects of Learning, 191-198.

Martin, L. E., \& Mulvihill, T. M. (2019). Voices in Education: Teacher Self-Efficacy in Education. The Teacher Educator, 54(3), 195-205.

McDaniel, M. A., \& Schlager, M. S. (1990). Discovery learning and transfer of problem-solving skills. Cognition and Instruction, 7(2), 129-159.

Meidawati, Y. (2013). Pengaruh Pendekatan Pembelajaran lnkuiri Tebimbing terhadap Peningkatan Kemampuan Pemecahan Masalah Matematis Siswa SMP. Universitas Terbuka.

Morris, D. B., Usher, E. L., \& Chen, J. A. (2017). Reconceptualizing the sources of teaching selfefficacy: A critical review of emerging literature. Educational Psychology Review, 29(4), 795-833.

Muchyidin, A. (2017). Pengaruh Penggunaan Bahan Ajar Matematika Bersuplemen Komik 
Terhadap Kemandirian Belajar Siswa. Eduma: Mathematics Education Learning and Teaching, 6(1), 43-51.

Mullis, I. V. S., Martin, M. O., Foy, P., Arora, A., \& others. (2012). TIMSS 2011 international results in mathematics. TIMSS \& PIRLS International Study Center Chestnut Hill, MA.

Mullis, I. V. S., Martin, M. O., Ruddock, G. J., O'Sullivan, C. Y., \& Preuschoff, C. (2014). TIMSS 2015. G4_Booklet_1. Chestnut Hill, MA: TIMSS \& PIRLS International Study Center, Lynch School of Education, Boston College.

Murni, V., Sariyasa, S., \& Ardana, I. M. (2017). GeoGebra assists discovery learning model for problem solving ability and attitude toward mathematics. J. of Phys: Conf. Series, 895, 16.

Norton, S. (2019). Middle school mathematics pre-service teachers' content knowledge, confidence and self-efficacy. Teacher Development, 23(5), 529-548.

Nugraha, G., Supianti, I. I., \& others. (2020). Penerapan Model Discovery Learning Untuk Meningkatkan Kemampuan Berpikir Kritis Matematis Siswa SMK. Pasundan Journal of Mathematics Education Jurnal Pendidikan Matematika, 10(1), 78-87.

Nugroho, H. A., Hidayah, I., \& others. (2020). Mathematical Literacy in Discovery Learning with Scaffolding Strategy Reviewed from Self Efficacy. Unnes Journal of Mathematics Education Research, 9(1), 44-51.

Nurdjito, N. (2013). Pre-Test pan Work Plan sebagai Strategi Pembelajaran Efektif pada Praktikum Bahan Teknik Lanjut Jurusan Pendidikan Teknik Mesin FT UNY. Jurnal Pendidikan Teknologi Dan Kejuruan, 21(4), 335-339.

Ormond, C. A. (2016). Scaffolding the Mathematical "Connections": A New Approach to Preparing Teachers for the Teaching of Lower Secondary Algebra. Australian Journal of Teacher Education, 41(6), 8.

Pajares, F. (1996). Self-efficacy beliefs in academic settings. Review of Educational Research, 66(4), 543-578.

Pajares, F. (2002). Overview of social cognitive theory and self-efficacy.

Patandung, Y. (2017). Pengaruh model discovery learning terhadap peningkatan motivasi belajar IPA Siswa. Journal of Educational Science and Technology (EST), 3(1), 9-17.

PISA. (2013). PISA 2012 results in focus: What 15-year-olds know and what they can do with what they know. Author Paris, France.

Prasasti, D. E., Koeswanti, H. D., \& Giarti, S. (2019). Peningkatan Keterampilan Berpikir Kritis Dan Hasil Belajar Matematika Melalui Model Discovery Learning Di Kelas Iv Sd. Jurnal Basicedu, 3(1), 174-179.

Prasetyana, S. D., Sajidan, S., \& Maridi, M. (2015). Pengembangan Model Pembelajaran Discovery Learning Yang Diintegrasikan Dengan Group Investigation Pada Materi Protista Kelas X SMA Negeri Karangpandan. INKUIRI: Jurnal Pendidikan IPA, 4(2), 135-148.

Purwaningrum, J. P. (2016). Mengembangkan kemampuan berpikir kreatif matematis melalui discovery learning berbasis scientific approach. Refleksi Edukatika: Jurnal Ilmiah Kependidikan, 6(2). 
Putra, A. A., Subhan, M., \& others. (2018). Mathematics learning instructional development based on discovery learning for students with intrapersonal and interpersonal intelligence (preliminary research stage). International Electronic Journal of Mathematics Education, 13(3), 97-101. https://doi.org/10.12973/iejme/2701

Qadri, L., Ikhsan, M., \& Yusrizal, Y. (2019). Mathematical Creative Thinking Ability for Students Through REACT Strategies. International Journal for Educational and Vocational Studies, 1(1), 58-61.

Rahmazatullaili, R., Zubainur, C. M., \& Munzir, S. (2017). Kemampuan berpikir kreatif dan pemecahan masalah siswa melalui penerapan model project based learning. Beta: Jurnal Tadris Matematika, 10(2), 166-183.

Ramdhani, M. R., Usodo, B., \& Subanti, S. (2017). Discovery learning with scientific approach on geometry. Journal of Physics: Conference Series, 895(1), 12033. https://doi.org/10.1088/1742-6596/895/1/012033

Rawlings, J. O., Pantula, S. G., \& Dickey, D. A. (2001). Applied regression analysis: a research tool. Springer Science \& Business Media.

Russell, B. (1993). Introduction to mathematical philosophy. Courier Corporation.

Schmid, R. F., Bernard, R. M., Borokhovski, E., Tamim, R., Abrami, P. C., Wade, C. A., Surkes, M. A., \& Lowerison, G. (2009). Technology's effect on achievement in higher education: a Stage I meta-analysis of classroom applications. Journal of Computing in Higher Education, 21(2), 95-109.

Schunk, D. H. (1995). Self-efficacy and education and instruction. In Self-efficacy, adaptation, and adjustment (pp. 281-303). Springer.

Shapiro, S. (2005). The Oxford handbook of philosophy of mathematics and logic. Oxford University Press.

Sibuea, S. K., Syaukani, W. N. N., \& others. (2019). Penerapan Model Discovery Learning dalam Pembelajaran Sejarah Kebudayaan Islam di MTS Darul Hikmah TPI Medan. EDURILIGIA: Jurnal Ilmu Pendidikan Islam Dan Keagamaan, 3(3).

Simamora, R. E., Saragih, S., \& others. (2019). Improving Students' Mathematical Problem Solving Ability and Self-Efficacy through Guided Discovery Learning in Local Culture Context. International Electronic Journal of Mathematics Education, 14(1), 61-72.

Simon, M. A. (2020). Elaborating reflective abstraction for instructional design in mathematics: Postulating a Second Type of Reflective Abstraction. Mathematical Thinking and Learning, 22(2), 162-171.

Siregar, Y. (2015). Kompetensi guru dalam bidang strategi perencanaan dan pembelajaran Matematika. Formatif: Jurnal Ilmiah Pendidikan MIPA, 3(1).

Sparks, S. D. (2014). An age-old problem gets new attention. Education Week, 33(34), 5-9.

Sriraman, B. (2009). The characteristics of mathematical creativity. ZDM, 41(1-2), 13.

Stacey, K. (2011). The PISA view of mathematical literacy in Indonesia. Journal on Mathematics Education, 2(2), 95-126.

Suciawati, V. (2016). Pengaruh Metode Penemuan terbimbing terhadap Kemampuan Berpikir 
Kreatif Matematik Siswa. (Doctoral dissertation, UNPAS)..

Suciawati, V. (2019). Pengaruh Self Efficacy terhadap Kemampuan Berpikir Kreatif Matematik Siswa. Jurnal Didactical Mathematics, 2(1), 17-22.

Sumarmo, U. (2010). Berpikir Dan Disposisi Matematik: Apa, Mengapa, dan bagaimana dikembangkan pada peserta didik. Bandung: FPMIPA UPI.

Sundayana, R. (2012). Upaya Meningkatkan Kemampuan Komunikasi Statistika Melalui Pemberian Praktikum Pengolahan Data Berbantuan Komputer pada Mahasiswa Prodi Pendidikan Matematika STKIP Garut. Mosharafa: Jurnal Pendidikan Matematika, 1(2), 51-58.

Suriany, E. (2016). Peningkatan kemampuan berpikir kreatif matematis siswa SMA melalui pembelajaran Math-Talk Learning Community. Indonesian Digital Journal of Mathematics and Education, 3(5), 2407-8530.

Suryadi, D. (2015). Refleksi Kritis Tradisi Pendidikan Matematika dan Sebuah Gagasan Alternatif. In Pendidikan Disiplin Ilmu Abad 21: Sebuah Kajian Prospektif. (pp. 122-147). UPI PRESS.

Sweller, J. (2004). Instructional design consequences of an analogy between evolution by natural selection and human cognitive architecture. Instructional Science, 32(1-2), 9-31.

Sweller, J., Kirschner, P. A., \& Clark, R. E. (2007). Why minimally guided teaching techniques do not work: A reply to commentaries. Educational Psychologist, 42(2), 115-121.

Tossavainen, T., Rensaa, R. J., \& Johansson, M. (2019). Swedish first-year engineering students' views of mathematics, self-efficacy and motivation and their effect on task performance. International Journal of Mathematical Education in Science and Technology, 1-16.

Utomo, A. P., Yuana, K., Narulita, E., Fikri, K., \& Wahono, B. (2018). Students' errors in solving science reasoning-domain of trends in international mathematics and science study (TIMSS). Jurnal Pendidikan IPA Indonesia, 7(1), 48-53.

van Rooij, E. C. M., Fokkens-Bruinsma, M., \& Goedhart, M. (2019). Preparing Science Undergraduates for a Teaching Career: Sources of Their Teacher Self-Efficacy. The Teacher Educator, 54(3), 270-294.

Wang, S.-L., \& Lin, S. S. J. (2007). The effects of group composition of self-efficacy and collective efficacy on computer-supported collaborative learning. Computers in Human Behavior, 23(5), 2256-2268.

Watson, S., \& Marschall, G. (2019). How a trainee mathematics teacher develops teacher selfefficacy. Teacher Development, 23(4), 469-487.

White, H., \& Sabarwal, S. (2014). Quasi-experimental design and methods. Methodological Briefs: Impact Evaluation, 8, 1-16.

Zhou, D., Du, X., Hau, K.-T., Luo, H., Feng, P., \& Liu, J. (2019). Teacher-student relationship and mathematical problem-solving ability: mediating roles of self-efficacy and mathematical anxiety. Educational Psychology, 1-17. 